\title{
Czynniki kostrukcyjne i technologiczne wpływające na żywotnośc osi zestawów kołowych
}

\begin{abstract}
Artykut jest poświęcony zabiegom konstrukcyjnym oraz technologicznym, majacym na celu zwiększenie żywotności osi pojazdów trakcyjnych oraz tocznych. Przedstawiono metody zwiększenia bezpieczeństwa i niezawodności osi zestawów kołowych na przykładzie wagonów towarowych. Poruszono istotne problemy zwiazane $z$ projektowaniem osi zestawów kołowych napędnych zespołów trakcyjnych dalekobieżnych, gdzie zaproponowano bardziej ostrożne podejście do przyjmowania naprężen dopuszczalnych, wynikających z bardzo dużego przebiegu kilometrowego, wynoszacego nawet $500000 \mathrm{~km} \mathrm{w}$ skali roku. Zaprezentowano nowoczesna metodyke projektowania osi zestawów kołowych pojazdów trakcyjnych dalekobieżnych oraz lokomotyw, która jest wynikiem zdobytych doświadczeń eksploatacyjnych. Osie takich pojazdów sq poddane obciqżeniom zmęczeniowym $w$ zakresie giga-cyklowym, a więc zdecydowanie większym od zakresu $10^{7}$ cykli, wynikajacym z krzywej Wöhlera. Podejście to porównano z metodyka przedstawiona $w$ normach europejskich PN-EN 13103+A1: 2011 (dla osi pojazdów tocznych) oraz PN-EN 13104+A1:2011 (dla osi pojazdów trakcyjnych). Omówiono istotny wkład $w$ zakresie rozwoju kryteriów technologicznych i badań odbiorczych osi zestawów kołowych, która wnosi norma europejska. Bardzo istotnym czynnikiem, wptywajacym na żywotność osi sq badania diagnostyczne, do których należy zaliczyć badania ultradźwiękowe oraz badania magnetyczno-proszkowe. PN-EN 13261+A1:2011. Artykul zostat opracowany $w$ ramach projektu badawczo-rozwojowego $\mathrm{Nr} \quad R \quad 10 \quad 004806 / 2009 \mathrm{pt}$. „Mikroprocesorowy system diagnostyczny głównych systemów trakcyjnego pojazdu szynowego uwzględniajacy ocene bieżqca i prognozowanie stanów”, finansowanego z budżetu Ministerstwa Nauki i Szkolnictwa Wyższego.
\end{abstract}

\section{Wprowadzenie}

Problematyka związana z rozwojem technologii wytwarzania osi zestawów kołowych jest wciąż aktualna. Rozwój tej technologii jest wynikiem wzrastających parametrów eksploatacyjnych, jakie muszą spełniać obecne pojazdy. Do podstawowych parametrów technicznych pojazdów, podlegającym zwiększeniu należą miedzy innymi prędkość, nacisk zestawu kołowego na tor oraz przebieg kilometrowy pojazdu przeliczony w skali rocznej. Zwiększenie tych parametrów jest wywołane wzrastającymi wymaganiami, stawianymi przez przewoźników kolejowych, w wyniku konkurencji na rynku transportowym. Oś zestawu kołowego nabiera więc jako element konstrukcyjny coraz większego znaczenia, decydującego o bezpieczeństwie eksploatacyjnym pojazdu trakcyjnego. Tym należy tłumaczyć coraz większy nacisk na rozwój:

- metod obliczeniowych, przedstawionych w PN-EN 13103:2011+A1 [15] oraz PN-EN 13104:2011+A1[16] oraz w [4,19],
- $\operatorname{metod}$ diagnostycznych $[1,3,8,9,11,12,14,20]$ oraz

- prognozowania pęknięć w osiach zestawów kołowych $[5,8,10]$.
Niewątpliwie do zwiększenia żywotności osi przyczynia się również technologia wykonania osi, która ma ostateczny wpływ na osiagnnięcie zakładanej granicy zmęczenia materiału. Norma PN-EN 13261:2011+A1 [17] przedstawia wymagania technologiczne w następujących zakresach:

- składu chemicznego,

- dopuszczalnych wad mikrograficznych,

- wymagań wytrzymałościowych,

- zabezpieczeń antykorozyjnych,

- dopuszczalnych naprężeń własnych.

2. Metody obliczeniowe wg norm europejskich, a doświadczenia eksploatacyjne

Doświadczenia eksploatacyjne zespołów trakcyjnych, przystosowanych do wysokich prędkości, zwłaszcza ICE w DB AG dostarczyły nowego materiału bazowego do analiz osi pod względem wytrzymałościowym. Przebieg kilometrowy zespołów trakcyjnych dalekobieżnych wynosi około $500000 \mathrm{~km} \mathrm{w}$ skali rocznej (ok. $1370 \mathrm{~km}$ w przeliczeniu na dzień, ok. $57 \mathrm{~km} \mathrm{w}$ przeliczeniu na jedną godzinę). Dla porównania przebieg zespołów trakcyjnych ruchu 
lokalnego wynosi około 100 000km w skali rocznej. Jak okazuje się z praktyki eksploatacyjnej przy takim intensywnym przebiegu już podczas 21 dni jest osiagnięta bazowa wartość cykli $10^{7}$ cykli. Zakładając średnią średnicę toczną koła $0,900 \mathrm{~m}$, wynika że oś jest obciążona 350 cyklami w przebiegu przeliczeniowym na jeden kilometr, co daje 484000 cykli obciążeń na jeden dzień. Z takich przeliczeń wynika, że zakładając 30-letnią żywotność otrzymuje się łączny przebieg, wynoszący 15 milionów kilometrów, co odpowiada $10^{9}$ cykli obciążeń $\left(100 \% 10^{7}\right.$ cykli obciążeń). $\mathrm{Z}$ tego wynika, że zakładana wartość $10^{7}$ cykli obciążeń jest w praktyce wielokrotnie przekraczana (nawet 100 razy). W związku z tym wytrzymałość eksploatacyjna takich elementów jak osie nabiera szczególnego znaczenia i zależy od wielu czynników, które są wymienione na rys.1.

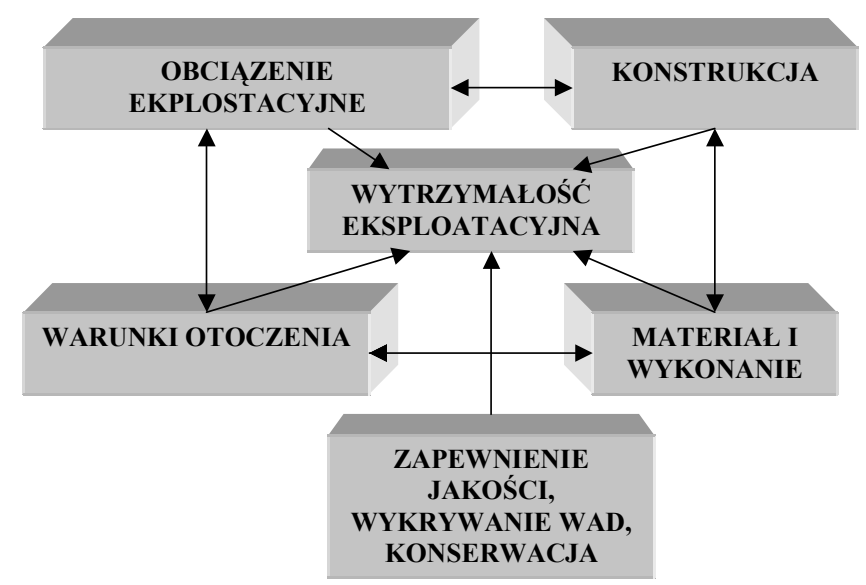

Rys.1. Schemat blokowy czynników mających wpływ na wytrzymałość eksploatacyjną osi zestawów kołowych wraz z ich wzajemnymi powiązaniami

Z przeprowadzonych badań naukowych i doświadczeń praktycznych znane są ograniczenia prostego opisu wytrzymałości zmęczeniowej. Jako istotne ograniczenia należy wymienić:

- najczęściej występujące obciążenia eksploatacyjne nie posiadaja charakteru sinusoidalnego, lecz są to obciążenia o zmiennym przebiegu, a wskutek tego występuje mechanizm kumulacji uszkodzeń o odmiennym charakterze

- na częściach występujących w eksploatacji nie można mówić o wytrzymałości zmęczeniowej w tradycyjnym ujęciu, wskutek czego po $10^{6}$ lub $10^{7}$ cykli obciążeń odnotowuje się dalszy spadek wytrzymałości co wyznacza krzywa o pochyleniu k2, szczególnie to odczuwa się przy połączeniach wtłaczanych (na odsadzeniach kół, łożysk, kół przekładni i tarcz hamulcowych) i przy występowaniu korozji
- warunek wytrzymałości zmęczeniowej dla osi jest spełniony, jeśli współczynnik bezpieczeństwa $\mathrm{S}$, definiowany jako stosunek pomiędzy naprężeniem dopuszczalnym oraz naprężeniem rzeczywistym. wynikającym z eksploatacji jest większy od 1.; w rzeczywistych warunkach eksploatacyjnych stosunek ten może być mniejszy w wyniku działania ekstremalnego naprężenia, spowodowanego wystapienia maksymalnej siły podczas przejazdu przez łuk toru.

\section{3. Żywotność osi zestawu kołowego wg krzywej Gassnera i Wöhlera}

Żywotność przy zmiennej amplitudzie naprężeń i wynikającym $\mathrm{z}$ tego układu naprężeń jest opisana przez krzywą Gassnera, która została zastosowana w budowie części pojazdów szynowych w latach 80tych. Krzywa Gassnera jest przedstawiona na rys.2.

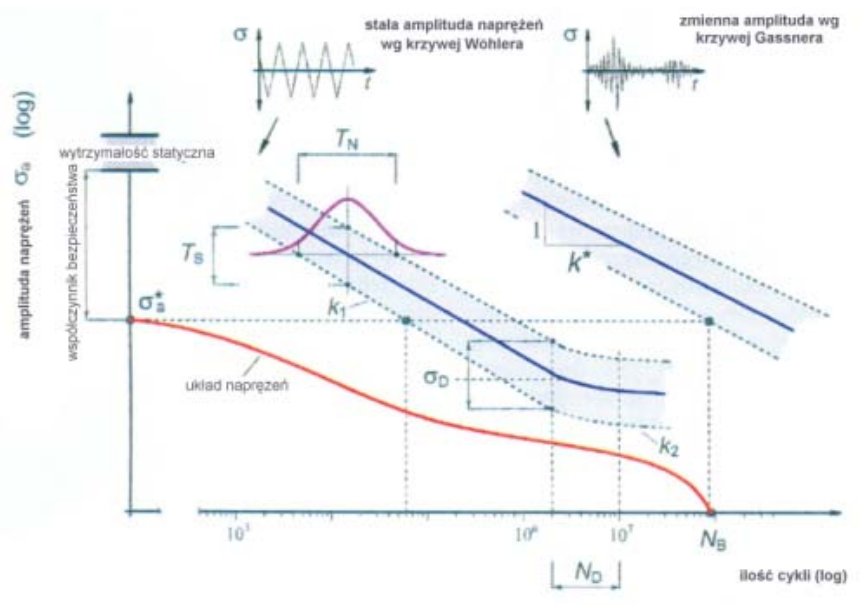

Rys.2. Określenie amplitudy naprężenia $\sigma_{a}$ wg hipotezy ekwiwalentnych uszkodzeń wg [3]

Została ona opracowana już w latach trzydziestych XX wieku i wykorzystana w projektowaniu lekkich konstrukcji w przemyśle lotniczym, a następnie wykorzystana również w budowie pojazdów. Również krzywa Gassnera została opisana przez rozproszenie i pochylenie $\mathrm{k}^{*}$. Krzywa Gassnera może być zastosowana do charakterystyki wytrzymałości zmęczeniowej przy określonych warunkach brzegowych oraz do oceny wytrzymałości eksploatacyjnej i żywotności przy znanym obciążeniu eksploatacyjnym. Przy przedłożeniu reprezentatywnego układu obciążeń jako układu do konstrukcji dla przewidywanej żywotności wywodzi się naprężenie ekwiwalentne dla uszkodzenia.

Naprężenie ekwiwalentne $\sigma_{a, a ̈ q}$, odpowiadające uszkodzeniu jest obciążeniem o przebiegu sinusoidalnym przy zdefiniowanej ilości cykli obciążeń $\mathrm{N}_{\mathrm{v}}$, które wywoła analogiczne uszkodzenie jak układ obciążeń z maksymalną wartością naprężenia $\sigma_{a \text {,betr }} \mathrm{i}$ ilości cykli obciążeń $\mathrm{N}_{\mathrm{B}}$. Naprężenie ekwiwalentne 
$\sigma_{a, a ̈ q}$ wyznacza się za pomocą hipotezy PalmgrenaMinera, przy czym wykorzystuje się pochylenie krzywej Wöhlera $\mathrm{k}_{2}=2 \mathrm{k}_{1}-1$ lub $\mathrm{k}_{2}=2 \mathrm{k}_{1}-2$, powyżej ilości cykli $\mathrm{N}_{\mathrm{v}}$ na podstawie przedłożonych danych, zebranych doświadczeń i zależnie od mechanizmów uszkodzeń. Niniejszy sposób postępowania określa się jako projektowanie dopasowane do warunków eksploatacyjnych, przy czym jest zagwarantowane, że wykazana jest wymagana żywotność, przy której unika się przedwczesnego pęknięcia części decydujących o bezpieczeństwie, do jakich należą osie lub koła zestawów kołowych. Jako podstawę do uszkodzenia bierze się za podstawę ,pęknięcie techniczne”, przy którym jest zachowana pełna funkcjonalność części.

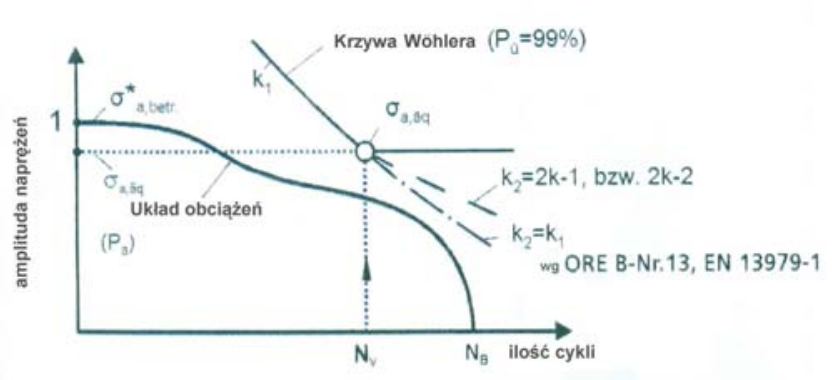

Rys.3. Określenie naprężenia „ekwiwalentnego”, odpowiadającemu uszkodzeniu

Jako miarodajną dla żywotności osi przyjęto więc ilość cykli obciążeń $\mathrm{N}_{\mathrm{B}} \approx 10^{9}$, odpowiadającą rzeczywistym warunkom eksploatacyjnym. Przyjęto założenie, że przy odpowiednim zaprojektowaniu osi (zwymiarowaniu osi) prędkość propagacji pęknięcia jest relatywnie mała i można przewidzieć normalne okresy międzynaprawcze. W przeciwieństwie do tego przy częściach, wykazujących mniejsze wymiary (,konstrukcja niedowymiarowana”) zwiększa się prawdopodobieństwo wystąpienia pęknięcia, przy określonych warunkach wytężenia materiału i prowadzi to do istotnie zmniejszonych okresów międzynaprawczych. Tak więc projektowanie osi zgodnie $\mathrm{z}$ obciążeniami eksploatacyjnymi nabiera również znaczenia ekonomicznego.

Dotychczasowe wyniki uzyskane z badań oraz zdobytych doświadczeń z przemysłu pokazały, że występuje logarytmiczny związek pomiędzy żywotnością L i naprężeniem $\sigma$ oraz pomiędzy średnicą przekroju osi d i żywotnością.

Żywotność osi określa się z zależności:

$$
\mathrm{L}_{\mathrm{X}}=\mathrm{L}_{\mathrm{B}}\left(\frac{\sigma_{a, B}^{*}}{\sigma_{a, b e t r}^{*}}\right)^{k^{*}}
$$

Zależność wymiarową wyznacza się wg wzoru:

$$
d_{B}=d_{X}\left(\frac{L_{B}}{L_{X}}\right)^{1 / n \cdot k^{*}}
$$

gdzie:

$\mathrm{L}_{\mathrm{x}}$ - oczekiwana żywotność przy występowaniu naprężenia eksploatacyjnego $\sigma_{a \text {,betr }}^{*}$

$\mathrm{L}_{\mathrm{B}}$ - żywotność odpowiadająca projektowaniu

$\sigma_{a, B}^{*}$ - naprężenie, które jest w stanie przenieść kon-

strukcja osi, aby osiągnąć żywotność $\mathrm{L}_{\mathrm{B}}$ osi zestawu kołowego;

$\mathrm{d}_{\mathrm{x}}$ - średnica rozpatrywanego przekroju osi

$\mathrm{n}$ - wykładnik naprężenia $(\mathrm{n}=1 \div 2$ dla wieńca i tarczy koła, $n=3$ dla osi zestawu kołowego)

$\mathrm{k}^{*}$ - wykładnik żywotności $\left(\mathrm{k}^{*}=5 \div 8\right.$, zależny od gradientu naprężenia, stanu powierzchni i stanu obciążenia w rozpatrywanej strefie elementu konstrukcyjnego).

Z oczekiwanej żywotności $\mathrm{L}_{\mathrm{x}}$ i wymaganej żywotności projektowej $\mathrm{L}_{\mathrm{B}}$ można ustalić wymagane zmniejszenie naprężeń $\sigma_{a, b e t r}^{*}$ względnie zwiększenie średnicy $\mathrm{d}_{\mathrm{x}} . \mathrm{Z}$ drugiej strony $\mathrm{z}$ naprężenia $\sigma_{a \text {,betrt }}^{*}$, które jest w stanie przenieść konstrukcja i ekwiwalentnego

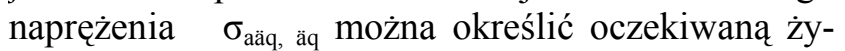
wotność $\mathrm{L}_{\mathrm{x}} \mathrm{W}$ porównaniu do wymaganej żywotności projektowej $\mathrm{L}_{\mathrm{B}}$ :

$$
L_{x}=L_{B}\left(\frac{\sigma_{a, \text { betr }}}{\sigma_{a, a q}}\right)^{k^{*}}
$$

Wg tego wzoru, wyrażającego zależność pomiędzy żywotnością i naprężeniami, naprężenie większe o $10 \%$ w stosunku do wartości naprężenia, które jest w stanie przenieść konstrukcja zmniejsza żywotność o współczynnik wynoszący 2 przy współczynniku pochylenia krzywej $\mathrm{k}^{*}=6$. Zwiększenie naprężenia o 10\% może być spowodowane zmniejszeniem średnicy przekroju osi o około 3\%. Obliczenia osi tocznych oraz trakcyjnych zespołu trakcyjnego dalekobieżnego ICE TD zostały wykonane w oparciu odpowiednio o PN-EN 13103:2011+A1 [17] oraz PN-EN 13104:2011+A1 [18]. Osie toczne były wykonane z materiału normalizowanego cieplnie EA1N (25CrMo4), natomiast osie trakcyjne $\mathrm{z}$ materiału ulepszanego cieplnie EA4T (34CrNiMo6). Naprężenia dopuszczalne przyjęto na podstawie ww. norm europejskich. Obydwa typy spełniały więc wymagania wytrzymałości zmęczeniowej we wszystkich strefach ze współczynnikami bezpieczeństwa $\mathrm{S}=\sigma_{\mathrm{a}, \mathrm{zul}} / \sigma_{\mathrm{a} \text {,betr }} \geq 1 \mathrm{wg} \mathrm{ww}$. norm. Oszacowanie żywotności wg metodyki projektowania wg widma $\mathrm{z}$ eksploatacji, przy założeniu przebiegu wynoszącego 15 milionów kilometrów prowadzi jednak do zupełnie innych rezultatów. Ponadto $\mathrm{z}$ pomiarów eksploatacyjnych ustalono, że uwzględnia się około $20 \%$ większe naprężenie w stosunku do obliczeń wg normy. Jeśli przyjąć, że dotychczasowy przebieg kilometrowy $\mathrm{L}_{\mathrm{X}}$ wynosił 3 miliony kilometrów (aż do 
ujawnionego pęknięcia w najbardziej wytężonym miejscu w łuku przejściowym), a wymagany wynosi $\mathrm{L}_{\mathrm{B}}=15$ milionów kilometrów to wówczas stosunek obydwu przebiegów wynosi $\mathrm{L}_{\mathrm{B}} / \mathrm{L}_{\mathrm{X}}=5$. Jeśli przyjąć, że $\mathrm{n}=3$ (dla osi) oraz $\mathrm{k}^{*}=6$ to wówczas zgodnie $\mathrm{z}$ zależnością (2):

$$
\mathrm{d}_{\mathrm{x}}=\mathrm{d}_{0} 3^{(1 / 3 \times 6)}=1.09 ? \mathrm{~d}_{0}
$$

Oznacza to, że w krytycznych miejscach osi średnica powinna wzrosnać o $9 \%$, aby spełnić wymaganie żywotności $L_{B}=15$ milionów kilometrów. Niniejszy wniosek dotyczył osi napędnej, co przełożyło się na zmianę średnicy osadzenia ze $179 \mathrm{~mm} \mathrm{z}$ łukiem przejściowym $160 \mathrm{~mm}$, na średnicę osadzenia 195 $\mathrm{mm} \mathrm{z}$ łukiem przejściowym $174 \mathrm{~mm}$. Z obliczeń wytrzymałościowych za pomocą metody elementów skończonych wynika, że największa koncentracja naprężeń występuje w strefie oznaczonej kolorem czerwonym, która jest przedstawiona na rys.4 (lewa strona).

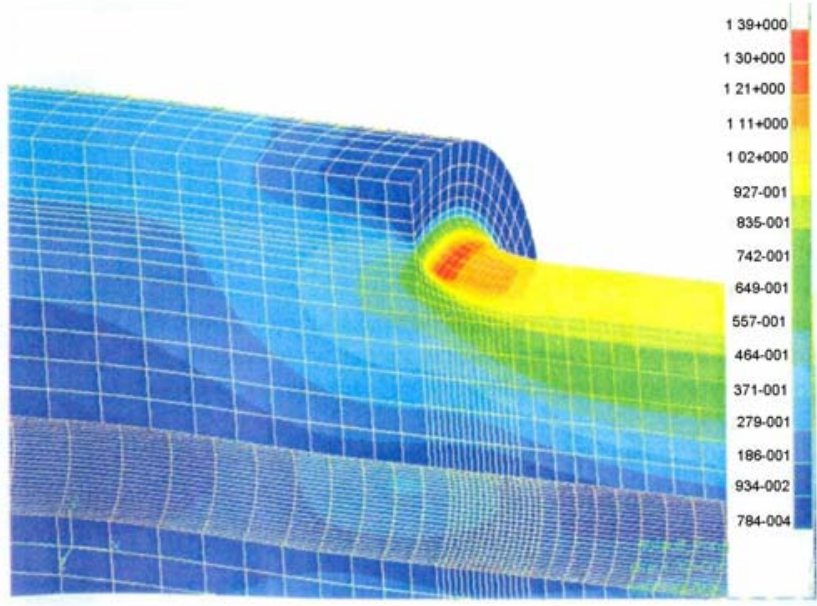

Rys.4. Usytuowanie pęknięcia zmęczeniowego w łuku osi napędnej zespołu trakcyjnego ICE 3, które wystapiło po 7,7 latach eksploatacji i przebiegu 3 milionów kilometrów (analiza wytrzymałościowa metodą elementów skończonych)

W wyniku analizy pęknięcia osi, które wystapiło w 2008 roku uznano, że jego przyczyną były zanieczyszczenia materiałowe, wynikające z procesu wytwarzania o długości ok. 0,9 mm, które przekroczyły dopuszczalną wartość.

Pękniecie osi trakcyjnej innego zespołu trakcyjnego dalekobieżnego typu ICE 3 wystąpiło na trasie Nürnberg-Chemnitz w dniu 2.12.2002 po rocznej eksploatacji i przebiegu wynoszącym około $350000 \mathrm{~km}$, który doprowadził do wykolejenia, nie powodując ofiar wśród pasażerów. Przełom zmęczeniowy osi w strefie osadzenia koła został spowodowany korozją cierną w tym rejonie.

Graficzne przedstawienie wytrzymałości zmęczeniowej osi zestawów kołowych wg obliczeń zgodnie z normą PN-EN 13103+A1:2011 (osie toczne) [17] oraz PN-EN 13104+A1:2011 (osie trakcyjne) [18] w zależności od ilości cykli obciążeń znajduje się na rys.5.

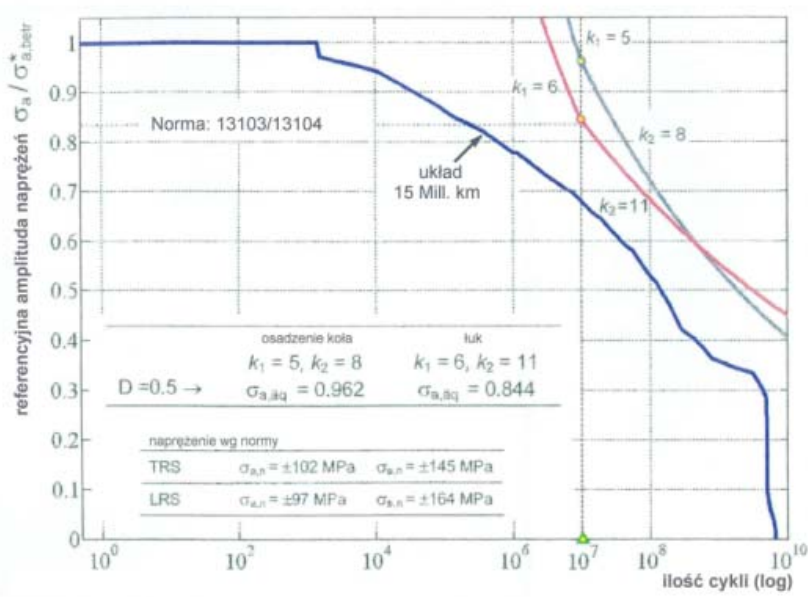

Legenda:

TRS - zestaw kołowy napędny (niem. Treibradsatzwelle)

LRS - zestaw kołowy toczny (niem. Laufradsatazwelle)

Rys.5. Oszacowanie wytrzymałości zmęczeniowej osi zespołu trakcyjnego ICE (osadzenie koła na osi) w zależności od ilości cykli obciążeń

\section{Zalecenia konstrukcyjne}

Jak wynika z przebiegu krzywej zmęczenia, naprężenia pomierzone są o ok. $30 \%$ wyższe aniżeli przedstawione $\mathrm{W}$ normie PN-EN13104:2011+A1 [18]. Okazuje się, że w takim przypadku projektowanie zestawów kołowych wg normy musi prowadzić bezwzględnie do uszkodzeń, ponieważ wychodzi się z fałszywych założeń. Po przejściowym zatrzymaniu 19-tu zespołów trakcyjnych typu ICE-3 dokonano wymiany wszystkich osi. Nowe osie posiadały nieznaczną modyfikację geometryczną i były pokryte molibdenem. W wyniku dokonanych zabiegów konstrukcyjnych można było osiagnąć tylko 10 letnią żywotność.

W związku z powyższym proponuje się:

- projektowanie obliczeniowe (konstrukcja) na podstawie obciążeń i danych obliczeniowych,

- sprawdzenie wytrzymałości za pomocą prób,

- sprawdzenie obciążeń na podstawie pomiarów na trasie,

- ostateczne ustalenie projektowanej konstrukcji, włączenie $\mathrm{z}$ planem przeglądów oraz kontroli międzynaprawczych.

Jako dodatkowy środek zaradczy, zwiększający niezawodność kursujących dalekobieżnych pojazdów trakcyjnych, przystosowanych do wysokich prędkości należy uznać kontrolę za pomocą sensorów właściwości eksploatacyjnych, między innymi kół i osi. Ten nowoczesny i kontrowersyjny pogląd na odmienne podejście do projektowania osi jest oparty na przekonaniu, że każdy doświadczony inżynier powinien mieć świadomość, że normy obowiązujące w kolejnictwie odpowiadają najniższemu poziomowi technicznemu, który jest uzgodniony przez fachow- 
ców i odbiegają mocno aktualnego stanu technicznego. Metodyka obliczeń osi dla takich przypadków powinna być porównana $\mathrm{z}$ innymi metodykami, które choćby są stosowane w innych działach techniki, do których zalicza się budowę samolotów lub samochodów. W wyniku przedstawionego rozumowania zaleca się, aby na instalować odpowiednie sensory $\mathrm{w}$ nowoczesnych pojazdach szynowych, aby dokonywać kontroli własności dynamicznych układów biegowych, a w szczególności osi i kół zestawów kołowych. Dodatkowym wsparciem dla nowego podejścia do projektowania zestawów kołowych jest wielkość niezrównoważonego przyspieszenia w zależności od zastosowanej przechyłki na łukach toru. Analizując niezrównoważone przyspieszenia $\mathrm{a}_{\mathrm{qc}} \mathrm{W}$ zależności od przechyłki toru, w raporcie ORE/ERRI B136/Rp.11/D [21] oraz PN-EN 13103:2011+A1 [17] przyjęto wartość przyspieszenia poprzecznego dla osi tocznych $\beta=0,15 \mathrm{~g}=1,47 \mathrm{~m} / \mathrm{s}^{2}$ natomiast $\mathrm{w}$ przypadku osi napędnych PN-EN 13104:2011+A1 [18] wartość $\beta=0,175 \mathrm{~g}=1,71 \mathrm{~m} / \mathrm{s}^{2}$.W przypadku bardzo dużych przechyłek toru, przeznaczonych dla pojazdów trakcyjnych z przechylnym pudłem niezrównoważone przyspieszenie jest znacznie większe aniżeli przyjęte w PN-EN 13103:2011+A1 [17] oraz PN-EN 13104:2011+A1 [18]. Widoczne to jest dla przechyłek toru o wartości większej niż $240 \mathrm{~mm}$. W związku z powyższym można wnioskować o trzech istotnych punktach, w których normy PN-EN 13103:2011+A1 [17] oraz PN-EN 13104:2011+A1 [18] posiadają istotne mankamenty, a mianowicie pominięcie:

- masy zestawu kołowego

- kołysania i ewentualnego przechyłu pudła

- zbyt małe współczynniki bezpieczeństwa dla dopuszczalnych naprężeń przy bardzo dużych niedostatecznościach przechyłki.

\section{Podsumowanie}

Problematyka projektowania osi, technologii wykonania oraz badań diagnostycznych jest cały czas przedmiotem konsekwentnego rozwoju w wyniku prowadzonych prac studialnych oraz doświadczalnych w krajach europejskich w ramach krajowych projektów badawczo-rozwojowych oraz pod nadzorem Unii Europejskiej. Do istotnych czynników prac badawczo-rozwojowych należy zaliczyć między innymi np. badania zmęczeniowe przeprowadzane na próbkach w skali 1:1 na specjalnych stanowiskach badawczych. Właściwe zaprojektowanie osi, jej technologia wytwarzania oraz utrzymanie poprawnego stanu technicznego należą do czynników gwarantujących niezawodność oraz dyspozycyjność pojazdu, co wpływa na jego wyniki przewozowe, a tym samym zwiększają pozycję transportu szynowego na rynku przewozowym $\mathrm{w}$ porównaniu do innych środków transportowych. Wszystkie ww. czynniki gwarantują dopiero osiagnięcie właściwego celu. Należy pamiętać, że na niezawodność osi zestawów kołowych ma wpływ również stan utrzymania innych elementów zwłaszcza łożysk tocznych. Bardzo częstym przypadek niewłaściwego stanu utrzymania łożysk (niedostatek smaru, jego nieprawidłowe właściwości, zbyt małe luzy promieniowe, uszkodzenia materiałowe) jest przyczyną ukręcenia czopa osi zestawu kołowego, co powoduje znaczne straty materialne w kursującym taborze oraz w infrastrukturze kolejowej. Dlatego tak istotne znaczenie ma również diagnostyka ze strony infrastruktury kolejowej, między innymi zainstalowanie urządzeń do przegrzanych maźnic oraz tarcz hamulcowych w rejonie toru kolejowego. Bardzo ważnym problemem jest między innymi przeprowadzanie badań diagnostycznych przez certyfikowany personel, uprawniony do przeprowadzania zarówno badań ultradźwiękowych oraz badań magnetoskopowych osi.

\section{Literatura.}

[1] Engelmann J., Wirtgen J., Nicolin J.: Europäisches Aktionsprogramm für die Güterwagensicherheit. Eisenbahntechnische Rundschau Nr. 11/2010.

[2] Gökcek E., Behrends V.: Automatisches Radsatzmonitoring für Güterwagen. ETR-Eisenbahntechnische Rundschau Nr.11/2010

[3] Grubisic V., Fischer V.: Sichere Bemessung von ICERadsatzwellen. Eisenbahntechnische Rundschau, Nr.1-2, 2011

[4] Gumbiowski M., Poschmann I., Bowi M., Bardehle T.: Oberfläschenschutz von Radsätzen. Eisenbahningenieur Nr.9/2002.

[5] Hasslinger H.: Lastannahmen für RadsatzwellenBestandsanalyse. Eisenbahntechnische Rundschau. Nr. 12, 12.2009.

[6] Liedgens K.: Inspektionskonzept für Radsatzwellen bei der Hamburger Hochbahn. Eisenbahningenieur. Nr. 3/2010.

[7] Malkiewicz T.: Metaloznawstwo stopów żelaza. PWN Warszawa-Kraków. Wydanie III.1976.

[8] Murawa F., Winkler M... Randschichtbehandelte Radsatzwellen. Eisenbahningenieur Nr.7/2007.

[9] Richard A., Sander M., Wirxel M., Lebehahn J.: Ermittlung von Inspektionsinterwallen mittels Risswachstumsuntersuchungen. Eisenbahningenieur. Luty 2010.

[10] Sobaś M.: Diagnostyka osi zestawów kołowych układów biegowych pojazdów trakcyjnych i tocznych. Pojazdy Szynowe nr 4/2010

[11] Sobaś M: Kryteria obiektywnej oceny prognozowanych stanów osi zestawów osi zestawów kołowych pojazdów trakcyjnych. Pojazdy Szynowe nr 1/2011.

[12] Sobaś M: Zabiegi technologiczne zwiększajace żywotność osi zestawów kolowych. Pojazdy Szynowe nr $4 / 2011$

[13] EN 473: Kwalifikacja i certyfikacja personelu do badań nieniszczacych. Ogólne zasady. Marzec 1993.

[14] EN 45013: Ogólne wymagania dotyczqce opinii $i$ akredytacji placówek certyfikujacych (ISO/IEC Tom 61:1996).1998. 
[15] Karta UIC 811-1: Warunki techniczne na dostawe osi zestawów kołowych dla pojazdów trakcyjnych $i$ wagonów.

[16] Karta UIC 960: Kwalifikacja i certyfikacja personelu odpowiedzialnego za prowadzenie badań nieniszczacych elementów zespolów pojazdów szynowych $w$ procesie ich utrzymania.2-gie wydanie $z$ grudnia 2001.

[17] PN-EN 13103:2011+A1: Kolejnictwo. Zestawy kołowe $i$ wózki. Osie zestawów kołowych tocznych. Zasady konstrukcji.

[18] PN-EN 13104:2011+A1: Kolejnictwo. Zestawy kołowe $i$ wózki. Osie zestawów kołowych napędnych. Zasady konstrukcji.
[19] PN-EN 13261+A1:2011: Kolejnictwo. Zestawy kołowe i wózki. Osie. Wymagania dotyczace wyrobu.

[20] PN-93/K-91045: Pojazdy trakcyjne. Osie zestawów kołowych. Wymagania i badania.

[21] Raport ORE/ERRI B136/Rp.11/D: Zestawy kołowe z nasadzanymi tożyskami tocznymi. Konstrukcja, utrzymanie i standaryzacja. Obliczenie osi zestawów kołowych dla wagonów towarowych $i$ osobowych. Utrecht, kwiecień 1979.

[22] OR-9666: „Diagnostyka układów biegowych pojazdów tocznych i trakcyjnych. IPS ,Tabor” Wrzesień 2010. 